\title{
Anthropocenic war: coronavirus and total demobilization
}

\author{
William Merrin ${ }^{1}$
}

Published online: 5 June 2020

(c) Springer Nature Limited 2020

\begin{abstract}
This paper argues that the covid-19 coronavirus pandemic of 2019-2020 constituted the first Anthropocenic war: as an anthropogenic virus and biological attack on the human body and as the first global pandemic requiring a truly global response since our recognition of the Anthropocene. The paper explores how each nation was forced by the virus into a pause of global connections and relationships and a war against the human body, with the 'total demobilization' and bunkerization of their domestic populations. With space cut-off, this became a war of time and of endurance, with relations reduced, as Virilio suggests, to those of the connected 'terminal citizen'. Beyond the civil war against the body, however, there was also the civil war within the domestic populations who were active participants in this imploded home front line, producing and sharing both feel-good and disciplinary propaganda and engaging in debates around politics, conspiracy theories and disinformation. The paper explores the problems governments face in remobilization, the new data regime of informational totalitarianism remobilization will help produce and the likely instability of the post-covid-19 international order. It concludes that this 'war' was only the beginning and that anthropogenic environmental factors will play an increasing role in human conflicts in coming years.
\end{abstract}

Keywords Coronavirus · Pandemic · Civil war · Demobilization · Information war · Anthropocene

'We are condemned to being-in ...'

(Sloterdijk 2009, 108)

\section{From levée-en-masse to levée-en-masse-medias}

On 23 August 1793, facing possible defeat in its revolutionary wars with Austria, Prussia, Spain, Britain and the United Provinces, as well as internal insurrections, the French National Convention issued a 'levée en masse'. Its opening point declared:

From this moment until that in which the enemy shall have been driven from the soil of the Republic, all Frenchmen are in permanent requisition for the service of the armies. The young men shall go to battle; the married men shall forge arms and transport provisions; the women shall make tents and clothing and shall serve in the hospitals; the children shall turn

William Merrin

W.Merrin@Swansea.ac.uk

1 Swansea University, Swansea, UK old linen into lint; the aged shall betake themselves to the public places in order to arouse the courage of the warriors and preach the hatred of kings and the unity of the Republic.

(Halsall 2020)

This call for mass conscription (literally, a 'mass uprising') would transform the French military, replacing the professional army within the year with a vast, national army of 800,000 trained soldiers made up of citizens. But the levée meant more than the creation of a mass army, being built on two key ideas. The first was a new relationship to the state, with an implicit post-revolutionary compact whereby all those united and protected as citizens owed a similar duty of protection to the state: from now on, the body of the citizen was intimately tied to the survival of the body politic. The second, following from this, was that the entire society would be mobilized to support the military. As Ernst Junger notes here, 'the image of war as armed combat merges into the more extended image of a gigantic labour process': now the military army is joined by - and to- 'the modern armies' of commerce, transport, foodstuff and munitions, until 'there is no longer any movement whatsoever-be it that of the homeworker at her sewing machine-without at least indirect use for the battlefield' (Junger 1991, 126). 
The levée-en-masse transformed warfare, with conscription and mass armies becoming common and, during conflict, states increasingly transforming themselves into war-time economies, diverting huge resources to military service. WWI saw the fruition of these processes, with the mass mobilization of populations for mass warfare, supported by the mass mobilization of home industries. For some, this mobilization was insufficient. In his 1930 essay 'Total Mobilization', Ernst Junger complained of Germany's only 'partial' mobilization (1991, 125). For revolutionary conservatives like Junger, true greatness required a 'total mobilization' with its 'unlimited marshalling of potential energies', a mobilization 'that requires extension to the deepest marrow' (1991, 126). This mobilization was itself a reflection of the kinetic rhythms of the machine age:

It suffices simply to consider our daily life, with its inexorability and merciless discipline, its smoking, glowing districts, the physics and metaphysics of its commerce, its motors, airplanes, and burgeoning cities. With a pleasure-tinged horror, we sense that here, not a single atom is not in motion-that we are profoundly inscribed in this raging process. Total mobilization is far less consummated than it consummates itself; in war and peace, it expresses the secret and inexorable claim to which our life in the age of masses and machines subjects us.

$(1991,128)$

The totally mobilized peace of modernity, therefore, prefigured and produced the total mobilization of modern war. Junger's hopes for a new German youth who would throw themselves into this project of renewal-through-mobilization soon found its expression in Nazism's blitzkrieg and the 'total mobilization' of WWII that definitively erased the difference between civilian life and military action.

Though conscription continued in the west in the postwar period, gradually the experience of war changed for its populations, becoming more remote from everyday life. By the time of the 1991 Gulf War, smaller, professional armies dominated again, defined now by their total mobilization not of men, but of technologies. By then, war itself was in crisis in the west, with questions being asked as to whether western societies could sustain casualties and still support military action. The solution was a new phase in the history of mobilization. With the military and media collaborating in the Gulf to produce and disseminate the global spectacle, domestic populations would now be mobilized as its audience. In this new levée-en-masse-medias, the public's role was to watch television: to consume the war, to follow the press briefings, marvel at the 'smart-bomb' footage and 'clean war' and applaud the military operation.

In this new imploded home front, 'war' now meant enjoying the scopic pleasures of a video-game war (Taylor 1998,
75; Knightley 2000, 483), with little risk for western combatants and none at all for its viewers. A Steve Bell cartoon of the time showed a penguin grandfather replying to his grandchild's question of what he did in the war with, 'Me? I watched television and I'm proud of it!' (Merrin 2019, 24). It was a model of war and mass-media mobilization that would dominate in the west in the following decades, through Kosovo in 1999, Afghanistan in 2001 and Iraq in 2003, albeit one increasingly left behind as the 'War on Terror' developed. With the move to unseen drone strikes and special-forces operations, it was better if no-one knew what was happening; hence, the public were effectively stood down. That demobilization would last until the 2020 covid-19 lockdown which inaugurated a new era of total demobilization.

\section{Anthropocenic war}

When the 2020 coronavirus pandemic broke, political leaders immediately reached for military metaphors. Xi Jinping vowed to wage a 'people's war' on the virus; in a speech on 16 March, Emmanuel Macron repeatedly declared France was 'at war'; on 17 March, Italy's special commissioner for the coronavirus emergency called for a 'war-time economy'; on 18 March, Donald Trump presented himself as a 'wartime president'; in his 23 March address to the nation, UK PM Boris Johnson told the public this was 'a fight' in which 'every one of us is directly enlisted', whilst on 6 April, the US surgeon general warned of the 'Pearl Harbour moment' coming for this generation (see Serhan 2020; Momtaz 2020; Woodward 2020). Of course, as many equally quickly pointed out, 'war' metaphors were neither accurate or helpful, as war is a purely human phenomenon, representing a clash of wills, to which a human solution is always possible, whilst the victims' deaths did not represent a personal failure to fight (Serhan 2020). Freedman notes all this but nevertheless suggests 'there are similarities between pandemics and war, especially if a realistic view of modern war is adopted' in terms of effects and governmental responses (Freedman 2020). But perhaps we can go even further? Perhaps our concept of 'war' itself needs redefining: perhaps, biologically, this is a war?

In 2000, the atmospheric chemist Paul Crutzen declared 'We are in the Anthropocene' (Ellis 2018, 1) — a proposed, new era marking the impact of humanity on the world, distinguished from the Holocene by the record of human activity in the geological strata. We have long known that humans have transformed the world and have done so since huntergathering times, but recent decades have seen a growing awareness that the scale and speed of human transformation has exponentially increased. Though the concept of the Anthropocene remains controversial, with disagreements as 
to what geological records to accept and when the Anthropocene began (with the mid-twentieth century being seen by many as a key moment), the broader trends it identifies in climate change, systemic pollution, the transformation of habitats and ecosystems and the loss of biodiversity are beyond dispute.

There is, of course, a long history of pandemics and plagues, stretching from the earliest time, through outbreaks like leprosy in eleventh-century Europe, the Black Death in mid-fourteenth-century Europe, the first of seven cholera pandemics in 1817, the Chinese plague from 1855, the 1875 Fiji measles pandemic, the 1889 Russian flu, the 1918 Spanish flu, the 1957 Asian flu, AIDS/HIV after 1981, through to contemporary outbreaks such as SARS. Many were spread by human activity and can thus be seen to have an anthropogenic element. Perhaps the most famous example here is the fifteenth-sixteenth-century 'Columbian Exchange' which included the transferral of small pox and other diseases to the Americas, killing up to $56 \mathrm{~m}$ people and eradicating entire civilizations (Ellis 2018, 95-96).

The global risk of a new pandemic had been known for decades, even appearing in popular culture. The first episode of the BBC's (1975) show Survivors opened with a flu virus escaping an Asian laboratory, globally spreading via air travel and ending, 50 minutes later, with $99 \%$ of the world's population dead. Health organization warnings of a global influenza pandemic became common over the following decades, being reinforced by the outbreak of SARS (November 2002-May 2004) and MERS (from April 2012 and again in 2015 and 2018). In September 2019, the Global Preparedness Monitoring Board (GPMB) report 'A World at Risk' claimed:

There is a very real threat of a rapidly moving, highly lethal pandemic of a respiratory pathogen killing $50-80$ million people and wiping out nearly $5 \%$ of the world's economy. A global pandemic on that scale would be catastrophic, creating widespread havoc, instability and insecurity. The world is not prepared (Ó Mongáin 2020)

Meanwhile, every year the World Health Organization (WHO) has released its 'Threats to Global Health' report, with the 'threat of a global influenza pandemic' appearing in its top-ten list in 2019 (WHO 2019).

Covid-19 proved to be an equivalent threat, launching its own microbiological assault on the human system. Like many pandemics, its scale, impact and potential long-term effects eclipsed that of many 'wars'. On 5 April, the total UK hospital deaths reached 5373 (ITV 2020), a figure exceeding, in just over a month, the death toll of British military servicemen across all conflicts since 1945. With the 9 April hospital toll of 980 deaths (Tidman 2020), the UK lost more lives in 1 day than servicemen killed in the near-38-year
Northern Ireland deployment, or than were lost in the Falklands War, Gulf War, Kosovo War, Afghanistan War and Iraq War put together. In the USA, on 29 April, the death toll of 58,964 exceeded within months the US death toll in the decades-long Vietnam War. The deadliest day of that war, 31 January 1968, saw only 246 servicemen killed, compared to days such as 8 May when the USA reported 2746 dead (Mulraney 2020). By 14 May, more Americans had died from covid-19 (over 75,000) than in the Vietnam, Afghanistan and Iraq wars put together $(65,096)$ (BBC 2020i).

Where Baudrillard in 1991 explained how the 'war' in the Gulf was really a 'nonwar' (Baudrillard 1995), here the nonwar of covid-19 had all the appearance of a war in its casualties, impact and long-term implications as a global, biological attack on the entire species. The covid-19 pandemic is essentially anthropogenic, as a zoonotic disease most likely arising out of changes in habitat and interaction with humans. Whilst the Wuhan wet market is not the proven source of the outbreak, these markets are an important example of humanly created transmissible environments. Though the dating of the Anthropocene is still open and though earlier anthropogenic pandemics have existed, we can see that covid-19 is the first global pandemic requiring a truly global response since our recognition of the Anthropocene. It is the first Anthropocenic World War.

\section{The event lockdown}

Covid-19 was intimately linked with globalization and the hyperconnected economy. Wuhan, a city of 11 million, is a major transportation hub, a centre of manufacturing and, as part of the post-2004 Rise of Central China plan, a hub of hi-tech production and research. Benefitting from the movement of rural workers to urban centres, the growth of cheap industrial labour, and developments in IT, communications, transport and shipping, it is closely tied to the global economy and globalization (Liu 2020). Even the wet market was linked to globalization in serving both the growing working population and in its trade in exotic animals for the wealthy. Despite this global character, few in the west understood the risks. Western exceptionalism, the belief that the virus would be contained in Asia and the unthinkability of similar restrictions meant the threat was ignored.

Those hit first were the countries most connected to China and the most globally connected. With its spread, the global system itself went into lockdown: global travel stopped, travel restrictions and quarantine were imposed and each nation forced its populations indoors. With it came a lockdown on international relations. The US-Iran hostility that, only weeks earlier, many feared would escalate into 'World War III' (Bogart 2020) was now forgotten, with Trump warning against any resumption (Barnes 2020). Conflict 
shifted instead into posturing and soft power, from Trump's insistence on calling it the 'Chinese virus' and attacks on the WHO as pro-Chinese (Al Jazeera 2020; Shear 2020), to China's post-lockdown reframing of themselves as benevolent global providers of PPE (The Economist 2020).

The lockdown of the international order was also $a$ lockdown of events, at least as far as national audiences were concerned, as covid-19 crowded out all other news. The only international news of note was how other nations were coping with their own lockdowns. The global system of communications was ruptured by the virus. A system defined by motion - by the hypercirculation of goods, commodities, people, money, data and communications-was fundamentally interrupted, slowed down and even paused, forced in its extremes into idleness, into furlough, even hyperredundancy. The whole remained in motion, but with its systems disrupted - with employment and consumption locked-downit lacked both its meaning and the means to complete its circuits.

The greatest symbol of this pause of the global was the fate of oil: the source of fuel for all global transport and motion. Demand crashed in the global lockdown and on 20 April for the first time ever, the price of US oil went negative, falling from $\$ 18$ a barrel to $\$ 38$ (Ambrose 2020a). Crucially, the cause of that crash was not simply the lack of demand but the immobility of the oil itself, as places to store the oversupply ran out. Now, tankers that a few weeks earlier were crossing the world laden with up to $2 \mathrm{~m}$ barrels sat motionless around the coasts of the world, full of the very means of movement itself (Ambrose 2020b).

\section{Total demobilization}

War, at its heart, is motion. Paul Virilio, the theorist of dromocracy, is fond of quoting Sun Tzu's claim 'Speed is the essence of war', as well as Frederick the Great's dictum, 'To win is to advance' (Virilio 1986, 133;55). Indeed, war's violence is, first of all, the violence of movement itselfthe speed of assault—recall, again, Sun Tzu: 'The onset of troops is like the rush of a torrent which will even roll stones along in its course' (Sun Tzu 2020, Ch.5, part 12). War, therefore, is the rapid transferral of bodies and energies from one point in space and time to another point already occupied by other bodies, with the aim of displacing or destroying them. It is a kinetic phenomenon with the destructive force and character of a projectile: one that begins and ends with movement, with mobilization and demobilization.

In the covid-19 world war, however, the entire war was demobilization. Within each nation, the mass of the population was immediately demobilized, being asked to do nothing, to not leave the house, to not move and to remain essentially inactive. In a reversal of the levée-en-masse and of Junger's call for 'total mobilization', this global, specieswide world war produced instead the total demobilization of the population. The essence of war reverses here from speed into immobility and inertia. Whereas, in modern societies, Junger suggests 'not a single atom is not in motion', ours immediately dedicated itself to eradicating it. If, for Virilio, the speed of contemporary weapons technologies brings an advantage over the enemy, in allowing us 'to gain fractions of seconds' $(1986,137)$, this was a war that worked in the opposite direction, with demobilization hoping to gain weeks, even months, worth of advantage. Whereas Marinetti proclaimed that the Futurists would glorify war, describing it as 'the world's only hygiene' (Marinetti 2009, 22), here the proto-Fascists desire to destroy human life reversed into a new defence of the human against covid-19: for today, for the period of viral infection, hygiene became the world's only war.

If this was the potential end of the species, it was a curious apocalypse, lacking, in the west at least, the pain, violence and collapse of civilization we had expected. Here, for many, the end was merely an entropic sloth, anaesthetized with alcohol and marked by longer hair, weight gain and binge watching. This was the apocalypse as a dull Sunday afternoon-as Alan Partridge's famous appeal to the heavens: 'Sunday, bloody Sunday!' (Brand 2014). For Virilio, when WWI ended as a war of space-as a war of movement-bogged down in the stalemate of the trenches, it became instead a 'war of attrition', a war of time, where 'duration was survival' (1986, 52-53;56). This was our fate too. With the lockdown closing down space and movement, this world war was turned into a war of time with duration again representing survival. To live meant to bunkerdown: to cut oneself off from space and survive time. Life was reduced to endurance, and especially to the endurance of oneself.

\section{Survival machines}

With the national invasion of the virus and the lockdown of events, there emerged instead a global civil war. Each infected nation withdrew, closed itself off and declared their own war on the virus. To win it, each nation had, first of all, to wage war on human life itself-on our very 'Being-in-the-world'.

This global, legal lockdown was historically unprecedented. Whole nations immediately transformed themselves into carceral societies-or rather, in our compliance, into self-incarcerated societies. This was a self-imposed house-arrest, a concept to be understood only secondarily in its legal sense, for the word 'arrest' means, first of all, 'to cause to stop' (from the late fourteenth-century-old French, 'arester', 'to stay, stop', with its roots in the Latin 'arrestare', 
meaning 'to stop, restrain'), and this was our primary experience. This stopping is traditionally a punishment, as the arrested person is imprisoned and refused space to move, whilst motionlessness has also been used as torture - central to the 'enhanced interrogation techniques' used against Iraqi prisoners at Abu Ghraib, for example, were 'stress positions', handcuffing people into painful, prolonged immobility. Here, therefore, we put ourselves under house arrest: we stopped ourselves, locked ourselves in and placed ourselves into stress positions, torturing the public body for weeks with enforced immobility. Or perhaps this was more medieval in tone-responding to the plague-like, miasmic threat with a self-siege warfare, with each individual retreating behind their walls to hold out with their stores?

This atmospheric element is important. Sloterdijk's 2002 book Terror From the Air explores the movement in the twentieth century from targeting the body to targeting the environment and the new 'military climatology' that resulted (Sloterdijk 2009, 19). Following Heidegger, he emphasizes how our 'Being-in-the-world' was always a 'Being-in-the-air or more exactly a Being-in-the-breathable' $(2009,48)$, tracing how chemical warfare, Nazi gas chambers and nuclear weapons created an 'unliveable milieu' $(2009,16)$, devastating the 'life world' $(2009,55)$. For Virilio, similarly, the 'new climactic reality' of environmental warfare and bombardment in WWII led, in response, to the discovery of the 'bunker form' - our new 'survival machines' (Virilio 1994, 39). 'Just as there are two times, the time of peace and the time of declared war', Virilio argues, 'there are two atmospheres and not just one': those we can breathe in and those which kill us $(1994,42)$. Hence, bunkers became 'a shelter for man in this critical period, the place where he buries himself to subsist' $(1994,46)$. So, in this lockdown, the terror from the air became a terror of the air, and military bunker architecture was democratized and generalized to all, as we locked ourselves in our 'casement' (literally, a 'stronghouse') (1994, 46). Being-in-the-world became Being-inthe-bunker, with Sloterdijk's claim that 'we are condemned to being-in ...' describing now not only the fatality of phenomenological reality, but the fate of the body within an unbreathable world.

There was something dystopian about the resulting exodus from public space, echoing science-fiction warnings of abandoned landscapes, from the domed, bunker cities of Logan's Run and Blake's 7 set on a ruined earth, to the environmental catastrophes of Ballard's The Drowned World and The Drought, to the emptied urban landscapes of The Twilight Zone's 'Where is Everybody?', Wyndham's The Day of the Triffids, I Am Legend and The Walking Dead. But this was a dream our military had long planned for us. During the Cold War, Samuel Cohen helped invent the neutron bomb, an 'enhanced radiation weapon' (ERW), which he claimed was more humane in killing fewer humans and leaving buildings intact (Strauss 2014). Covid-19 had a curiously similar effect: the explosion of this enhanced biological weapon and our desperate bunkerization showing us a world without us in it. Stories spread of the environment's recovery-the reduction in industrial emissions (Regan 2020) and animals reclaiming the world-and a new photographic-essay genre emerged of covid-19-emptied cities (Liubchenkova 2020; Manning 2020; The Guardian 2020). These realized for us an impossible vision: a post-human sublime of our own perfectly preserved and lost civilization; a Pompeii-of-the-present we could appreciate online from within the self-buried safety of our survival machines.

It was a self-burial anticipated in E.M. Forster's 1909 novella 'The Machine Stops' which tells the dystopian tale of a future humanity, locked into vast, underground, honeycomb tiers of individual, hexagonal 'cells', cut off from the real world, with fully automated services and tubes and screens bringing everything to the immobilized individual, under the aegis of a single, networked 'machine' (Forster $2013,5 ; 15 ; 43 ; 47)$. Here, there is a 'terror' of physical contact, human proximity and real-world experience (2013, $12 ; 15)$, hence Vashti's horror at the idea of meeting her son, as 'people never touched one another. The custom having become obsolete owing to the machine' $(2013,18)$. It is a world where travel outside is illegal, where the greatest threat is 'homelessness' - being forced outside - and where muscles are discouraged (2013, 21-23). Instead, each individual self-isolates, connected through the machine to all they need, busying themselves consuming content and producing their own for their 'several thousand' friends (2013, 50). It is a world that is instantly recognizable.

This is the world too of Virilio's 'terminal citizen' (Virilio 1997, 21). We pass, Virilio says, from a society of speed to a society of immobility and inertia (1997, 20), moving with the 'transmission revolution' to the final human vehicle, the 'static' audio-visual vehicle: 'the body terminal of that interactive being who is both transmitter and receiver' (1997, 21; 11) For Virilio, this immobilized, 'generalized interactivity' $(1997,21)$ is a threat to our experience:

Paul Klee hit the nail on the head: 'To define the present in isolation is to kill it'. This is what the teletechnologies of real-time are doing: they are killing 'present' time by isolating it from its here and now, in favour of a commutative elsewhere that no longer has anything to do with our 'concrete presence' in the world, but is the elsewhere of a 'discreet telepresence' that remains a complete mystery.

(1997, 10-11)

It is hard to read this without thinking of our lockdown in an isolated, hyperextended present, disconnected from the real experience of time and space and engaging through real-time interfaces. For Virilio, this loss of the terrestrial 
body has another, theological meaning: as the loss of motion ('anima' - the root of 'animation') is also the loss of our soul (Latin: 'anima') $(1997,25)$. Hence, the body terminal, in only being 'mobile on the spot' $(1997,20)$, is fundamentally a terminal body.

In committing us to this condition, therefore, the lockdown saved lives by killing life. Our 'survival machines' became our sarcophagi, ultimately threatening to be more dangerous than going out. As Virilio says, 'stasis is death' (1986, 67).

\section{Global civil war}

The key battleground in this war against covid-19 was the reversed home front of everyday life. Where previously the 'front line' was the battlefield, supported by logistics and medical aid, with the 'home front' far removed, now the home-front was the battlefield, with the front line even reversing behind this to encompass the medical and logistical workers (the health and care staff and gig-economy workers) who risked their lives to keep the home front alive. In recognition of this service, UK tabloid The Sun began a campaign to award the George Cross media for gallantry to the NHS itself (Fairbairn 2020).

'Everyday life' had long been theorized by post-war western Marxists as a key site of ideological contestation and a space requiring liberation (Lefebvre 2014, 2016; Vaneigem 1994). Marx, in The German Ideology, famously ruminated on the future eradication of the division of labour for a life allowing one to hunt, fish, rear-cattle and criticize as one wished, 'without ever becoming hunter, fisherman, herdsman or critic' (Marx 2020), whilst the Situationists dreamed of a liberation from drudgery and the opportunity for selfrealization. As Raoul Vaneigem convincingly explains:

In an industrial society which confuses work and productivity, the necessity of producing has always been an enemy of the desire to create. What spark of humanity, of possible creativity, can remain alive in a being dragged out of sleep at six every morning, jolted about in suburban trains, deafened by the racket of machinery, bleached and steamed by meaningless sounds and gestures, spun dry by statistical controls, and tossed out at the end of the day into the entrance halls of railway stations, those cathedrals of departure for the hell of weekdays and the nugatory paradise of weekends where the crowd communes in a brutish weariness? From adolescence to retirement each twenty-four hour cycle repeats the same shattering bombardment ...

(Vaneigem 1994, 52)

Against this bombardment, Vaneigem hymned the 'rage to live', but covid-19 perhaps exposed these dreams. Though some spent their time refining their craft skills, for most the experience of liberation from both the division of labour and consumerist leisure owed more to Blaise Pascal's 1670 claim that 'All of humanity's problems stem from man's inability to sit quietly in a room alone' (Pascal 1995, 37). With selfisolation, Sartre's 'Hell is ... other people!' reversed itself upon ourselves (Sartre 2000, 223).

What saved us from the entropic death of bunkerized terminal boredom was our activity: our participation in this civil war. This was a complex, intra-state conflict defined not only by the fight of the human body and the body politic with the virus, but also by the division within the population between those promoting demobilization and those resisting it. Unlike in 1991 where the Gulf War levée-en-masse-medias mobilized the far-removed western public as audiences, in this imploded home-front-line the Web 2.0 revolution transformed us into active participants in the war: into vital keyboard warriors whose primary targets were not the virus but each other. In the UK, this meant the devotion of the public to the creation of both feel-good and disciplinary propaganda.

Here, the UK public joined the government and media in producing and sharing heart-warming, humorous and human-interest stories, as well as memes, gifs, inspirational quotes and videos to raise war-time morale. Hence, the endless media and social media paid attention to pensioners walking up stairs to raise money, 'Captain Tom' walking round his garden, care-home residents singing and public applause for health workers (Young 2020; BBC 2020a; Kiddey 2020; Robertson 2020). In this war-time lockdown, a simulacral 'blitz-spirit' dominated UK sentiment, celebrating public resilience and 'suffering' and treating events such as Boris Johnson's recovery and the birth of his child as rousing victories. The 8 May 75 th anniversary of VE day seemed to implode time itself, with the street parties, singalongs, Johnson's simulated Churchillianism and the Queen's speech seeming to convince people it was 1945 and that they personally had done their duty and achieved something great. One family even retreated into 1945, banning technology, wearing period costume and running nighttime air-raid drills (Johnston 2020).

The BBC played a key role here. Just as the British Broadcasting Company, afraid of losing its licence in 1926, took the opportunity of the General Strike to secure its future by turning itself into a compliant government mouthpiece (Williams 1998, 98-101), so too, in 2020, did a BBC that only weeks earlier was facing an 'existential threat' to its service and funding (Barker and Di Stefano 2020) take the opportunity of covid-19 to demonstrate its value as a national unifier and feel-good, war-time propagandist. Whilst $60 \%$ of the population thought it was doing a good job (Fletcher et al. 2020), on key issues such as austerity-era underfunding, lack of pandemic preparedness, testing, PPE stocks and the care-home death toll the 
government received only light-touch questioning from the $\mathrm{BBC}$, whose bulletins favoured instead sentimental, diversionary human-interest stories and charity efforts. Their interest in 'Captain Tom' transformed the national shame of needing a 99-year-old to walk round his garden to fund basic PPE for NHS staff into the feel-good media event of the lockdown (BBC 2020b).

The participant-warrior's role, however, was not just to produce positive propaganda. They also devoted themselves to public-policing, denouncing any activity departing from the legal code of the lockdown (UK Government 2020a), discovering the 'enemy within' in anyone abusing the 'permitted exercise' or 'reasonable excuse' to leave the house. Social media feeds, Twitter, community Facebook groups and messaging apps burned with outrage at the "covidiots', social-shaming food waste, poor social distancing, poor queuing, unnecessary shopping, park sunbathing and ball-games (see Carr 2020; Layton 2020; Noor 2020). And opposed to this were all those determined to resist the code and its policing, those determined to travel and exercise, those unhappy at the new police state and those annoyed by the social-shamers. Across the whole range of social media, covid etiquette and shaming flame wars played out in real time, all accompanied by photographs of offenders. Just as Virilio claims that today 'arms of communication' prevail over 'arms of destruction' (2002, 113-114) so, in this lockdown, we were simultaneously the demobilized, telespectators of this war against the human body and the active, hypermobilized, telepresent producer of our own informational civil war, deploying our personal arms of communication against the covidiot enemy.

This informational civil war included the online battle against conspiracy theories. The US and European far-right, especially, promoted disinformation and the scapegoating of particular groups (Doward 2020; Parveen 2020; Wilson 2020), whilst others promoted anti-5G claims (Tempterton 2020), leading to phone masts being vandalized and phone workers abused (Waterson and Hern 2020). Coronavirus 'deniers' spread their message around Facebook, YouTube, Instagram and Whatsapp (Randall 2020), prompting takedown actions and anti-Fake News responses by platforms and governments (Carrie Wong 2020a; Chadwick 2020a, b; Hern 2020; PA Media 2020; BBC 2020c). But the civil war also had an important, on-the-ground reality. Virilio's theory of 'dromocracy' (of governments of speed) suggests different speed classes-different 'orders of speed' $(1986,119)$ exist: hence, the lockdown class division between those who did not have to move and those who did: the health and care workers, delivery drivers, and warehouse and retail workers who faced the risk of exposure and death; and hence, the division too between those for whom money continued to move into their accounts and those for whom it stopped.
Then, there were the other inequalities in the civil war, with higher death rates for those in poorer areas, for Black and Asian minority ethnic people, and for men, the elderly and those with existing medical conditions (BBC 2020d; Siddique and Marsh 2020; Duncan 2020). The UK government especially waged a war on the vulnerable, preparing for the expected surge in hospital demand by mass evacuating the ill and weak back into their homes with little or no care, or into care homes, which became centres of infection. For weeks, the protection of care workers and rising number of care-home deaths were ignored, with the latter left out of official hospital-death figures (BBC 2020e). Add to this, the problems of the elderly, ill or vulnerable getting supplies; the rise in mental-health problems including self-harm and suicide (Mills 2020; Mohdin 2020); families going hungry (Iqbal 2020); a rise in domestic violence (Graham-Harrison et al. 2020); lockdown murders; the digital divide of those without adequate Internet access (Kelly 2020); the rise in problem-drinking (Campbell 2020); a rise in online child exploitation and child abuse imagery (Solon 2020); increased online videos of abuse and nonconsensual sex (Grant 2020); and an increase in cybercrime with new, covid-19-related scams (UK Government 2020b). We had long got used to the idea of civilian 'collateral damage' in the wars we watched on television, but in this imploded home-front-line, the collateral damage was us.

In the west, the USA experienced the most intense covid19 civil war. Instead of unifying the country, Trump, more concerned with his polls and re-election, seemed determined to exculpate himself, blame others and push political and cultural divisions. Having failed to act for 6 weeks, leading to the world's highest death toll (Pilkington and McCarthy 2020), Trump used his press conferences to attack political opponents and journalists (Spocchia 2020; Reuters 2020; Smith 2020b), to play his own 'propaganda video', praising himself (C-Span 2020) and to divert anger towards China and the WHO (BBC 2020g; Smith 2020a; BBC 2020h). One report, on 27 April, calculated he had spent 27 times longer in his press conferences attacking his personal enemies than expressing sympathy for the bereaved (Spocchia 2020). The need for a scientifically based response was especially problematic for an administration built on anti-scientific and proconspiracy credentials (Pilkington 2020), and Trump seemed determine to troll his own advisors, praising the virus as 'a genius' (Cockburn 2020), pushing his 'hunches' about drugs (Carrie-Wong 2020b) and speculating about injecting disinfectant (BBC 2020f). Throughout the crisis, Trump also pursued direct conflict with state governors regarding policy decisions and equipment availability (McCarthy 2020a; Naughtie 2020; Wallace Wells 2020).

Trump's posturing increasingly risked an actual civil war, with his tweets calling for people to 'liberate' Minnesota, Michigan and Virginia, his support for far-right linked 
anti-lockdown protests (Smith 2020c) and his claim that his presidential authority over state lockdown rules was 'total' (McCarthy 2020a, b). In an echo of his comments on Charlottesville's 'very fine people' (Klein 2018), Trump tweeted his support for the hundreds of 'very good people', some heavily armed, who massed at the Michigan state capitol on 30 April (Beckett 2020; Liptak 2020). Ongoing antilockdown protests, encouraged by Trump, were increasingly dominated by far-right militia groups and conspiracists, prompting fears of serious political violence (Perkins 2020). Whilst Trump's critics saw his handling of the crisis as a disaster, in fact he was playing to his strengths. What Trump achieved was to transform the covid-19 civil war into an extension of his already successful political and cultural civil war against the American people and its democratic institutions. This was politics as a continuation of civil war by identical means.

\section{Remobilization}

In his 1990 essay, 'Postscript on the Societies of Control', Gilles Deleuze argues we have left behind the nineteenthcentury Foucauldian 'disciplinary societies' and moved to new 'societies of control' (Deleuze 1992, 3-4). We have passed from societies defined by concentration, enclosure and the disciplinary power of incarceration-to new computer $(1992,6)$ and code-based $(1992,5)$ technologies and systems whose 'modulation' $(1992,4)$ allows 'continuous forms of control' $(1992,7)$. His example of this in practice is Guattari's suggestion of 'a control mechanism' able to track an individual around a city in real time, with electronic systems modulating behaviour by giving or withdrawing access $(1992,7)$. In the space of months, we repeated this historical trajectory, turning first back into societies of incarceration, before our gradual remobilization-passing back out into the world through the continuous controls of digital surveillance.

This was not easy. Recent years had seen the systematic pathologization of the Internet, as the optimism of Web 2.0's participative society gave way to an antipathy to public over-participation and fear of manipulation. By the time covid-19 hit, the Internet was seen as an out-of-control 'toxic' realm of trolling, abuse, death threats, hate speech, political extremism, populism, Russian hacking, information warfare and disinformation, 'fake news', electoral manipulation by paid, targeted advertising, cybercrime, government surveillance and mass-harvested personal data with few privacy protections. Almost overnight, this reversed again, with the real world and human relations becoming toxic and the Internet being transformed into our saviour, allowing safe work, education, entertainment and communication. Within weeks, we became, like the cell-bound inhabitants of Forster's tale, afraid of human contact. The outside world was no longer a site of possible risk, but instead was absolutely impure. 'The sacred', Caillois writes, 'is always more or less "what one cannot approach without dying" (2001, 21 ), and this was how we now treated life. The arbitrary $2 \mathrm{~m}$ distancing was treated as a meeting point between the safe, profane and the sacred world of contagion, impurity and death: to get close to another was not simply a risk, it was a passage between orders of being.

Hence, remobilization was more difficult and anxious than demobilization. In the UK, the relaxation of restrictions was confusing and the suggestion that some could return to work emphasized the reality of speed classes, with middle classes more able to remain at home, teleworking, whilst the working classes had to take their chances with public transport and work (Jones 2020). Despite the most effective model of remobilization being the labour-intensive process of mass testing, contact tracing and isolation, many nations preferred technological solutionism, embracing the continuous controls of digital surveillance, with electronic tagging replacing house arrest. China pioneered this approach, as a logical extension of their massive, near-ubiquitous surveillance system deployed against the Uighurs in Xinjiang (Wall Street Journal 2017; Byler 2019) and the 'social credit' systems and facial-recognition cameras used against their domestic populations (Mistreanu 2018; Dudley 2020). Here, CCTV facial recognition, drones, QR codes, location tracking by telecoms and technology companies and voluntary or mandatory apps formed a network of sensors enmeshing individuals in exactly that city-wide 'control-mechanism' Guattari foresaw. The same systems were widely adopted beyond China, highlighting an underlying trend within global political systems: the movement of all governments towards informational totalitarianism.

We are still too bewitched by twentieth-century totalitarianism-distracted by the spectacle, uniforms, speeches and rallies, the symbolism, and the public terror. Nazi Germany, Stalinist USSR, Maoist China were all hypervisible, aesthetically organized states aiming to abolish the separation of public and private life, to lay everything open to its eye-especially by force-and fulfil Mussolini's dreams of 'totalitario': 'All within the state, nothing outside the state, none against the state'. Now, at a historical distance from its political theatrics, the essence of totalitarianism is finally revealed: it is about the right of the state to penetrate-to oversee - the totality of life within it. This is, clearly, an informational project. Stripped of its politico-aesthetics and aided by the rise of digital technology, it reverses now from spectacle to secrecy and from public to private, to silently access, monitor and evaluate every aspect of personal interiority and singularity.

Hence, totalitarianism quietly fulfils itself today as an ideology of transparency: of absolute recording, access and 
exposure. It is freed here not only from the burden of terror, the manpower of policing and the cost of costumery, but, most importantly, from ties to any political system or ideology, existing simply as the technocratic aim and result of digital systems. Today, therefore, even western liberal democracies are informationally totalitarian, in their mass surveillance, their treatment of personal data and their systems of monitoring and control, in their desire-no different to that of authoritarian regimes-to access everything and their absolute conviction that they have the right to do so. Once again, this is for our benefit-what was once for our 'security' is now for 'public health' - but it nevertheless remains an internal attack on the data integrity of the state's own citizens. The US and UK governments had joked about this, archly naming two of their spy programmes, 'Bullrun' and 'Edgehill', after Civil War battles (Ball et al. 2013). That data civil war against private data has continued without a pause since Snowden's revelations, and it is likely that the advances allowed by the covid-19 crisis will never be rolled back.

The heart of the post-covid-19 'new normal', therefore, will not be the physical regimes of cleanliness and distancing but the new data regime. We thought this had already been accomplished in the existing system of 'surveillance capitalism' (Zuboff 2019), but covid-19 will supercharge this process, representing the moment when our public and private spaces and lives imploded, opening up previously limited areas for total data colonization. As Naomi Klein argues, 'the future that is being rushed into being as the bodies still pile up treats our past weeks of physical isolation not as a painful necessity to save lives, but as a living laboratory for a permanent — and highly profitable—no-touch future'. It is a future 'in which our homes are never again exclusively personal spaces, but are also, via high-speed digital connectivity, our schools, our doctor's offices, our gyms, and, if determined by the state, our jails' (Klein 2020). It is the future of the bunkerized terminal citizen, with an increasing reliance on Internet and phone infrastructures and remotely delivered services and systems, delivering ever-greater quantities of personal data to private companies and states.

The work of remobilization will be one of the great state projects of our lifetime. The movement of bodies out of homes, of labour into the work place, of the market back to life and the recirculation of capital will require great effort. The cardiac-arrest of capitalism-saved in the UK only through the effective nationalization of the economy and a simulacral-communist state responsibility for the economic and physical welfare of the population-will require a massive defibrillation of the economy to shock it back to life, but there are doubts as to how fast this can be achieved. The IMF has warned that the world faces the worst recession since the Great Depression (BBC 2020j), or, for the UK, for '300 years' (Morris 2020), whilst the WHO warns that covid-19 'may never go away' (BBC 2020k). With this economic 'slowdown', the covid-19 civil wars will continue to be fought within each nation for years to come.

The remobilization of the world order will also be difficult. On 7 May, Trump commented that impact of the coronavirus on the USA was 'worse than Pearl Harbor ... worse than the World Trade Center' (BBC 20201). Judged by casualties, this is certainly true (the 73,573 coronavirus deaths by 7 May far eclipsed the 2403 deaths at Pearl Harbor or 2977 killed in 9/11), but the meaning of those events really lay in their political significance and impact on the world order. If we consider the global scale of this pandemic, the global lockdown of populations, the global death toll, the halt to economic and international relations and the differential and ongoing impact of the virus, we can see that covid-19 may prove an event of equally, or potentially, greater historical significance. There was pre-covid-19, and there was the time after its first great wave.

\section{The new world disorder}

The hyperconnected world of global travel and contact will take a long time to recover and as with domestic life, much that can be transferred online will be. International conflict will not end but one possibility is nations will be more inward looking and less interested in others. On 12 May, it was revealed, for example, that the UK's National Security Council had not met since January, with the government focused on covid-19 (Sabbagh 2020). Military action may be more difficult with the expected slashing of military budgets and a possible mindset that might resent spending on international action or aid when the domestic economy remains to be fixed (Warrell 2020). The emphasis may shift, therefore, to strengthening the national and civilian infrastructure in anticipation of future human, or human-created threats. Military action is also physically difficult right now, with the need for social distancing impacting on military bases, ships and submarines, on training and exercises, and parades and future operations.

But that is why we can expect an acceleration of one particular trend in warfare. Since the 1991 Gulf War, with the allied air supremacy that allowed them to bomb with utter impunity, through the zero-casualty aerial 1999 NATO Kosovo War, to the development of drones, the USA has led the way in socially-distanced warfare. We can expect to see the post-covid-19 explosion, therefore, of drones, surrogate robotics and autonomous systems, all controlled from remote shipping containers or box-room bunkers. This will be a new phase of clean war, defined now not by the absence of civilian casualties but by the hand sanitizer available for the next shift of pilots and the plastic screen between them and the camera and weapons operators. Here, the act 
of washing one's hands before taking over the controls will take on a macabre moral dimension.

There are other reasons why conflict may have an expanded future. In a world where international powers are more reluctant to intervene, regional powers will have far more leeway to pursue their aims. China's ongoing actions in the South China Sea (Nicol 2020) and imposition of new security laws in Hong Kong (Kuo and Davidson 2020) are one example of this, but others have seen the opportunity. Data analytics company Babel Street recorded an apparent increase in military activity in May by Iran. Despite being badly hit by covid-19, Iran's support for offensive cyberoperations and for proxy forces in Yemen and Iraq rose in the previous 2 weeks (Tucker 2020a).

International conflict has continued online during the pandemic. Already poor US-Chinese relations have worsened, as Trump tries to direct domestic anger towards China and as China tries to divert international attention from the virus's origins and their poor handling of medical reports. This has all the making of a new, viral, respiratory cold war. As the US Cybersecurity and Infrastructure Security Agency noted, 'China and other authoritarian governments have promoted false claims about the origins of the virus in an attempt to shift blame overseas and divide free societies against themselves', using tactics such as 'censoring news, injecting false narratives onto social media platforms and promoting slick government-produced videos' (Baksh 2020). On 29 April, for example, China's state-run news agency Xinhua posted an animated video titled 'Once Upon a Virus', showing Lego-like figures representing China and the US trading barbs at each other, with the US Statue of Liberty getting progressively sicker whilst claiming 'The virus is not dangerous. But millions of Chinese are dead. Even though the virus is not dangerous. We are correct. Even though we contradict ourselves' (Timsit 2020). This was not traditional state propaganda. Designed as viral, sharable social media content, this was troll-warfare. Instead of a hot war, China had launched a burn war against the USA. It did not matter that its own claims were false, here you win with the lulz.

Beyond China, Russia and Iran were also using the opportunity to extend their online disinformation campaigns against the west (Beaumont et al. 2020; Tucker 2020b). Even cyberwar was changing, with espionage now targeting not military, political or economic secrets, but research into the coronavirus and vaccines, as reports emerged of China, Russia and Iran hacking western laboratories (Cole 2020a, b; Davidson 2020). Overall, we can expect computer network exploitation (CNE), disinformation, propaganda and trolling to continue with, perhaps, greater impact.

The post-covid-19 era has the potential for considerable national economic, political and social instability, including backlashes against governments and their responses, the scapegoating of particular groups, unrest at the economic impact so soon after the 2008 crash and its enforced 'austerity', and a more nationalist, isolationist, anti-globalitarian mood. The UK lockdown, for example, prompted a surge in hate crimes against Asian communities (Grierson 2020), and continuing anger, hostility and fear seem likely to be one inheritance of this crisis. The entire post-covid-19 world will be more unpredictable and more volatile. The virus did not affect each nation the same, and within each country, the responses of governments and populations will be different. Globally, an already fragile world order-still recovering from the 2008 crash, suffering the after-effects of the 'War on Terror', facing the reassertion of Russian power and the rise of China and India, hit by the retreat of liberal democracy, the success of populist strongmen leaders and ethnonationalist movements, and struggling with long-term civil wars, refugees and immigration flows, climate change and a US president pursuing an unpredictable, random and oftendangerous foreign policy-will only become more unstable. If the seismic political shift of the fall of Communism in 1991 led many to speculate about a possible 'New World Order', the seismic political shift of covid-19 brings the possibility of an epoch-defining New World Disorder.

\section{The war of the world}

H. G. Wells' 1897 novel The War of the Worlds told the story of the Martian invasion of earth and the alien's eventual defeat, not by human hands, but 'by the putrefactive and disease bacteria against which their systems were unprepared' (Wells 2019). The book was an attack on hubris, using 'invasion literature' to question both evolutionary theory and imperialism and the idea that humanity in general, and Victorian, colonial Britain in particular, were superior to all others: for how superior were we if we had to be saved by 'the humblest things that God, in his wisdom, has put upon this earth'? Actually, bacteria were not the smallest things - it would take years before the much smaller viruses were discovered-but Wells was correct about our hubris. Although in his 'scientific romance' these bacteria were our 'microscopic allies', we failed, in the subsequent years, to take seriously the threat of these microbial forces. Covid19 was a reminder of the power of the world and our place within it. With this anthropogenic pandemic, The War of the Worlds gave way to its inevitable sequel: the War of the World.

Why the battle against covid-19 and the concept of Anthropocenic War are important is because they help us recognize that, from now on, human conflict will be increasingly accompanied by, exacerbated or even sparked by anthropogenic environmental factors. Environmental change or phenomena will increasingly impact upon human 
societies, destabilizing them, creating poverty and increasing political violence and competition. Hence, the Anthropocene has definitively announced itself as the final global superpower, replacing the limited realms of human state power with its own, singular, environmental force. The aftershocks of covid-19 will be serious, as it spreads through the global south, as it pits nations into competition, as it introduces new pressures into areas already riven by natural disasters, civil war, or political extremism, as it impacts domestically on each nation's economy, politics and world view and as it destabilizes the international order.

Given the likelihood of more pandemics to come and the growing impact of anthropogenic environmental problems, the first Anthropocenic war will not be the last. The war of the world will continue.

\section{References}

Al Jazeera 2020. Trump defends calling coronavirus the 'Chinese virus'. Al Jazeera News, 23rd March. https://www.aljazeera.com/ programmes/newsfeed/2020/03/trump-defends-calling-coron avirus-chinese-virus-200323102618665.html.

Ambrose, Jillian. 2020a. Oil prices dip below zero as producers forced to pay to dispose of excess. The Guardian, 20th April. https:// www.theguardian.com/world/2020/apr/20/oil-prices-sink-to-20year-low-as-un-sounds-alarm-on-to-covid-19-relief-fund.

Ambrose, Jillian. 2020b. Oil market faces storage crisis in a world awash with crude. The Guardian, 25th April. https://www.thegu ardian.com/business/2020/apr/25/oil-market-storage-crisis-coron avirus-plummeting-demand.

Baksh, Mariam. 2020. China is spreading coronavirus disinformation, CISA warns. Defense One, 11th May. https://www.defenseone .com/threats/2020/05/china-spreading-coronavirus-disinforma tion-cisa-warns/165313/?oref=defenseone_today_nl.

Ball, James, Julian Borger, and Glenn Greenwald. 2013. Revealed: how US and UK spy agencies defeat internet privacy and security. The Guardian, 6th September. https://www.theguardian.com/world /2013/sep/05/nsa-gchq-encryption-codes-security.

Barker, Alex, and Mark Di Stefano. 2020. BBC faces biggest threat in decades, says head of news. Financial Times, 29th January. https://www.ft.com/content/825db83c-42a7-11ea-a43a-c4b32 8d9061c.

Barnes, Julian E. 2020. Trump warns Iran of heightened retaliation for any attacks on U.S. Troops. New York Times, 1st April. https ://www.nytimes.com/2020/04/01/us/politics/trump-iran-warni ng.html.

Baudrillard, Jean. 1995. The gulf war did not take place. Sydney: Power Publications.

BBC. 1975. The fourth horseman. Survivors, episode 1, 16th April. https://www.youtube.com/watch?v=zAyjkaFYnzE.

BBC. 2020a. Captain Tom Moore raises nearly $£ 33 \mathrm{~m}$ as NHS appeal closes. BBC News, 1st May. https://www.bbc.co.uk/news/ukengland-beds-bucks-herts-52498156.

BBC. 2020b. Captain Tom Moore: How the war veteran captured our hearts. BBC News, 30th April https://www.bbc.co.uk/news/ uk-52316856.

BBC. 2020c. Coronavirus: Fake news crackdown by UK government. BBC News, 30th March. https://www.bbc.co.uk/news/technology $-52086284$
BBC. 2020d. Coronavirus: Higher death rate in poorer areas, ONS figures suggest. $B B C$ News, 1st May. https://www.bbc.co.uk/ news/uk-52506979.

BBC. 2020e. Coronavirus: Care home deaths 'far higher' than official figures. BBC News, 19th April. https://www.bbc.co.uk/ news/uk-52341403.

BBC. 2020f. Coronavirus: Outcry after trump suggests injecting disinfectant as treatment. BBC News, 24th April. https://www. bbc.co.uk/news/world-us-canada-52407177.

BBC. 2020g. Coronavirus: Trump stands by China lab origin theory for virus. BBC News, 1st May. https://www.bbc.co.uk/news/ world-us-canada-52496098.

BBC. 2020h. Coronavirus: US to halt funding to WHO, says trump. BBC News, 15th April. https://www.bbc.co.uk/news/world-uscanada-52289056.

BBC. 2020i. The lost six weeks when America failed to control the virus. BBC News, 14th May [BBC Video]. https://www.bbc. co.uk/news/world-us-canada-52656959.

BBC. 2020j. Coronavirus: "World faces worst recession since great depression". BBC News, 14th April. https://www.bbc.co.uk/ news/business-52273988.

BBC. 2020k. Coronavirus may never go away, World Health Organization warns. BBC News, 14th May. https://www.bbc.co.uk/ news/world-52643682.

BBC. 20201. Trump says coronavirus worse 'attack' than Pearl Harbor. BBC News, 7th May. https://www.bbc.co.uk/news/world -us-canada-52568405.

Beaumont, Peter, Julian Borger, and Daniel Boffey. 2020. Malicious forces creating 'perfect storm' of coronavirus disinformation. The Guardian, 24th April. https://www.theguardian.com/world 12020/apr/24/coronavirus-sparks-perfect-storm-of-state-leddisinformation.

Beckett, Lois. 2020. Armed protesters demonstrate against Covid-19 lockdown at Michigan capitol. The Guardian, 30th April. https ://www.theguardian.com/us-news/2020/apr/30/michigan-prote sts-coronavirus-lockdown-armed-capitol.

Bogart, Nicole. 2020. Twitter is convinced 'World War 3' is imminent after U.S. kills Iran's top general. CTV News, 3rd January. https://www.ctvnews.ca/world/twitter-is-convinced-world-war3-is-imminent-after-u-s-kills-iran-s-top-general-1.4752020.

Brand, Stewart. 2014. Alan partridge sunday bloody sunday. Youtube, 23rd January. https://www.youtube.com/watch?v=6RTJ4 vHoYUs.

Byler, Darren. 2019. China's hi-tech war on its Muslim minority. The Guardian, 11th April, https://www.theguardian.com/ news/2019/apr/11/china-hi-tech-war-on-muslim-minority-xinji ang-uighurs-surveillance-face-recognition.

C-Span. 2020. The coronavirus 'propaganda' video Trump played to media. The Guardian, 14th April. https://www.theguardia n.com/world/video/2020/apr/14/the-coronavirus-propaganda -video-trump-played-to-media-video.

Caillois, Roger. 2001. Man and the sacred. Urbana: University of Illinois Press.

Campbell, Denis. 2020. Problem drinking soars under UK lockdown, say addiction experts. The Guardian, 3rd May. https://www. theguardian.com/society/2020/may/03/problem-drinking-soars -under-uk-lockdown-say-addiction-experts.

Carr, Jemma. 2020. 'The madness continues': Social media users slam 'wasteful' panic-buyers who are still throwing away perfectly good food after stockpiling more than they can consume. Daily Mail, 30th March https://www.dailymail.co.uk/ news/article-8168489/Social-media-users-slam-wasteful-panic -buyers-throwing-away-perfectly-good-food.html.

Carrie Wong, Julia. 2020a. Tech giants struggle to stem 'infodemic' of false coronavirus claims. The Guardian, 10th April. https 
://www.theguardian.com/world/2020/apr/10/tech-giants-strug gle-stem-infodemic-false-coronavirus-claims.

Carrie-Wong, Julia. 2020b. Hydroxychloroquine: How an unproven drug became Trump's coronavirus 'miracle cure'. The Guardian, 7th April. https://www.theguardian.com/world/2020/apr/06/ hydroxychloroquine-trump-coronavirus-drug.

Chadwick, Jonathan. 2020a. Twitter is removing tweets that promote fake coronavirus treatments like 'drinking bleach', conspiracy theories that claim it's 'propaganda for soap companies' and posts that deny scientific facts in major crackdown. Daily Mail, 19th March. https://www.dailymail.co.uk/sciencetech/artic le-8129055/Twitter-remove-fake-coronvirus-treatment-conte nt.html.

Chadwick, Jonathan. 2020b. Facebook to send myth-busting messages to users who have liked, reacted or commented on posts containing 'harmful misinformation' about the coronavirus. Daily Mail, 16th April. https://www.dailymail.co.uk/sciencetech/artic le-8225779/Facebook-send-messages-users-engaging-fake-news. html.

Cockburn, Harry. 2020. 'Dangerous idiot': Trump says 'germ is so brilliant antibiotics can't keep up with it' in chaotic White House coronavirus meeting. The Independent, 11th April. https://www. independent.co.uk/news/world/americas/us-politics/trump-antib iotics-coronavirus-white-house-briefing-brilliant-enemy-geniu s-idiot-a9460636.html.

Cole, Harry. 2020a. Iran and Russia launch hacking attacks on British universities in attempt to steal coronavirus vaccine secrets. Daily Mail, 2nd May. https://www.dailymail.co.uk/news/article-82810 91/Iran-Russia-launch-hacking-attacks-British-unis-attempt-steal -vaccine-secrets.html.

Cole, Harry. 2020b. Kremlin-linked cyber hackers steal hundreds of medical trial records from British coronavirus lab. Daily Mail, 10th May. https://www.dailymail.co.uk/news/article-8304095/ Kremlin-linked-cyber-hackers-steal-hundreds-medical-trial-recor ds-British-coronavirus-lab.html.

Davidson, Helen. 2020. China hacking poses 'significant threat' to US Covid-19 response, says FBI. The Guardian, 14th May. https:// www.theguardian.com/world/2020/may/14/china-hacking-poses -significant-threat-to-us-covid-19-response-says-fbi.

Deleuze, Gilles. 1992. Postscript on the societies of control. Winter 59: 3-7. https://cidadeinseguranca.files.wordpress.com/2012/02/ deleuze_control.pdf.

Doward, Jamie. 2020. Far right hijack coronavirus crisis to push agenda and boost support. The Guardian, 25th April. https://www.thegu ardian.com/world/2020/apr/25/far-right-hijack-coronavirus-crisi s-to-push-agenda-and-boost-support.

Dudley, Lauren. 2020. China's ubiquitous facial recognition tech sparks privacy backlash. The Diplomat, 7th March. https://thediploma t.com/2020/03/chinas-ubiquitous-facial-recognition-tech-spark s-privacy-backlash/.

Duncan, Pamela. 2020. Men die of coronavirus at twice women's rate in England and Wales. The Guardian, 16th April. https://www. theguardian.com/world/2020/apr/16/men-die-of-coronavirus-attwice-womens-rate-in-england-and-wales.

Ellis, Erle C. 2018. Anthropocene. A very short introduction. Oxford: Oxford University Press.

Fairbairn, Emily. 2020. NHS heroes should be awarded the George Cross medal for gallantry-Including those who made the ultimate sacrifice. The Sun, 15th April. https://www.thesun.co.uk/ news/11406447/nhs-heroes-george-cross-medal-gallantry/.

Fletcher, Richard, Antonis Kalogeropoulos, and Rasmus Kleis Nielsen. 2020. News media broadly trusted as source of coronavirus information, views of UK government response highly polarised. Reuters Institute, 28th April. https://reutersinstitute.politics.ox.ac. uk/news-media-broadly-trusted-source-coronavirus-informatio n-views-uk-government-response-highly.
Forster, Edward Morgan. 2013. The machine stops. Rockville: Wildside Press.

Freedman, Lawrence. 2020. Coronavirus and the language of war. New Statesman, 11th April. https://www.newstatesman.com/ science-tech/2020/04/coronavirus-and-language-war.

Graham-Harrison, Emma, Angela Giuffrida, Helena Smith, and Liz Ford. 2020. Lockdowns around the world bring rise in domestic violence. The Guardian, 28th March. https://www.thegu ardian.com/society/2020/mar/28/lockdowns-world-rise-domes tic-violence.

Grant, Harriet. 2020. Urgent action needed as rise in porn site traffic raises abuse fears, say MPs. The Guardian, 25th March. https:// www.theguardian.com/global-development/2020/mar/25/urgen t-action-needed-as-spike-in-porn-site-traffic-raises-abuse-fears -say-mps.

Grierson, Jamie. 2020. Anti-Asian hate crimes up 21\% in UK during coronavirus crisis. The Guardian, 13th May. https://www.thegu ardian.com/world/2020/may/13/anti-asian-hate-crimes-up-21in-uk-during-coronavirus-crisis.

Halsall, Paul. 2020. Modern history sourcebook: The levée en masse, August 23, 1793. Internet Modern History Sourcebook, 21st January. https://sourcebooks.fordham.edu/mod/1793levee.asp.

Hern, Alex. 2020. WhatsApp to impose new limit on forwarding to fight fake news. The Guardian, 7th April. https://www.thegu ardian.com/technology/2020/apr/07/whatsapp-to-impose-newlimit-on-forwarding-to-fight-fake-news.

Iqbal, Nosheen. 2020. Exclusive: Almost a fifth of UK homes with children go hungry in lockdown. The Guardian, 3rd May. https ://www.theguardian.com/society/2020/may/03/exclusive-fifth -of-uk-homes-children-hungry-lockdown.

ITV. 2020. Coronavirus death toll rises in UK to 5,373. ITV News, 6th April. https://www.itv.com/news/2020-04-06/coronaviru s-death-toll-rises-in-uk-to-5-373/.

Johnston, Harriet. 2020. Mother-of-two reveals she made her family live in a 1945 time warp during lockdown-Banning technology and practicing air raid drills by waking her children with the sound of bombs. Daily Mail, 20th May. https://www.daily mail.co.uk/femail/article-8339393/Mother-two-reveals-famil y-live-1945-time-warp-lockdown.html.

Jones, Owen. 2020. Boris Johnson's message to the working class: Good luck out there. The Guardian, 12th May. https://www. theguardian.com/commentisfree/2020/may/12/boris-johnsonworking-class-good-luck.

Junger, Ernst. 1991. Total mobilization. In The heidegger controversy, ed. Richard Wolin, 119-139. New York: Columbia University Press.

Kelly, Annie. 2020. Digital divide 'isolates and endangers' millions of UK's poorest. The Guardian, 28th April. https://www.thegu ardian.com/world/2020/apr/28/digital-divide-isolates-andendangers-millions-of-uk-poorest.

Kiddey, Chris. 2020. 'We'll meet again': South Yorkshire care home residents perform Vera Lynn classic during coronavirus lockdown. ITV News, 8th April. https://www.itv.com/news/calen dar/2020-04-08/we-11-meet-again-south-yorkshire-care-homeresidents-perform-vera-lynn-classic-during-coronavirus-lockd own/.

Klein, R. 2018. Trump said 'blame on both sides' in Charlottesville, now the anniversary puts him on the spot. ABC News, 12th August. https://abcnews.go.com/Politics/trump-blame-sides -charlottesville-now-anniversary-puts-spot/story?id=57141 612.

Klein, Naomi. 2020. Naomi Klein: How big tech plans to profit from the pandemic. The Guardian, 13th May. https://www.theguardia n.com/news/2020/may/13/naomi-klein-how-big-tech-plans-toprofit-from-coronavirus-pandemic.

Knightley, Phillip. 2000. The first casualty. London: Prion Books. 
Kuo, Lily, and Helen Davidson. 2020. Hong Kong crisis: China presents security laws banning subversion and separatism. The Guardian, 22nd May. https://www.theguardian.com/world /2020/may/22/chinas-national-security-law-ban-subversion -and-separatism-hong-kong.

Layton, Josh. 2020. Outrage as bins overflow with Brits' out-of-date food bought in coronavirus panic. The Mirror, 28th March. https://www.mirror.co.uk/news/uk-news/coronavirus-outragebins-pictured-filled-21773469.

Lefebvre, Henri. 2014. Critique of everyday life, 1st ed. London: Verso.

Lefebvre, Henri. 2016. Everyday life in the modern world. London: Bloomsbury.

Liptak, Kevin. (2020) Trump tweets support for Michigan protesters, some of whom were armed, as 2020 stress mounts. $C N N$, 1st May. https://edition.cnn.com/2020/05/01/politics/donald-trump -michigan-gretchen-whitmer-protests/index.html.

Liu, Andrew. 2020. Blaming China for coronavirus isn't just dangerous. It misses the point. The Guardian, 10th April. https://www.thegu ardian.com/commentisfree/2020/apr/10/blaming-china-coron avirus-pandemic-capitalist-globalisation-scapegoat.

Liubchenkova, Natalia. 2020. In pictures: Deserted cities as anti-coronavirus lockdowns introduced around the globe. Euronews, 6th April. https://www.euronews.com/2020/03/18/in-pictures-deser ted-cities-as-anti-coronavirus-lockdowns-introduced-around-theglobe.

Manning, James. 2020. In pictures: the beauty of empty cities around the world. Time Out, 23rd March. https://www.timeout.com/trave 1/in-pictures-beautiful-empty-city-streets.

Marinetti, Filippo Tommaso. 2009. The founding and manifesto of futurism. In Futurist manifestos, ed. Umbro Apollonio. London: Tate Publishing.

Marx, Karl. 2020. The German ideology. Marxists Internet Archive. https://www.marxists.org/archive/marx/works/1845/germa n-ideology/ch01a.htm.

McCarthy, Tom. 2020a. Trump v the states: How the president is remaking the government in his image. The Guardian, 11th April. https://www.theguardian.com/us-news/2020/apr/11/trump -states-governors-clashes.

McCarthy, Tom. 2020b. Trump claims 'total authority' and attacks media in chaotic coronavirus briefing. The Guardian, 14th April. https://www.theguardian.com/world/2020/apr/13/trump-us-coron avirus-briefing-latest-media.

Merrin, William. 2019. Digital war. Oxon: Routledge.

Mills, Jake. 2020. Lockdown misery is turning a viral pandemic into a mental health crisis. The Independent, 25th March. https://www. independent.co.uk/voices/coronavirus-symptoms-mental-healt h-lockdown-social-distancing-a9424401.html.

Mistreanu, Simina. 2018. Life inside China's social credit laboratory. Foreign Policy, 3rd April. https://foreignpolicy.com/2018/04/03/ life-inside-chinas-social-credit-laboratory/.

Mohdin, Aamna. 2020. Warning over 'hidden effect of coronavirus' after grandfather's suicide. The Guardian, 30th April. https:// www.theguardian.com/uk-news/2020/apr/30/pick-up-the-phone -to-loved-ones-urges-man-after-grandfathers-suicide.

Momtaz, Rym. 2020. Emmanuel Macron on coronavirus: 'We're at war'. Politico, 16th March. https://www.politico.eu/article/ emmanuel-macron-on-coronavirus-were-at-war/.

Morris, Nigel. 2020. Coronavirus: UK faces 'worst recession for 300 years as grim economic impact of Covid-19 emerges. $i$ News, 7th May. https://inews.co.uk/news/health/economic-impact-coron avirus-uk-faces-worst-recession-300-years-2845666.

Mulraney, Frances. 2020. More Americans have died from coronavirus in three months than were killed in Vietnam War in 20 years as death toll tops 58,000 and more than one million are infected. Daily Mail, 29th April. https://www.dailymail.co.uk/news/artic
le-8267277/More-Americans-killed-COVID-19-three-month s-entire-Vietnam-War.html.

Naughtie, Andrew. 2020. Coronavirus: Trump clashes with governors over lack of testing kits in leaked call. The Independent, 31st March. https://www.independent.co.uk/news/world/ameri cas/us-politics/trump-us-coronavirus-testing-leaked-call-gover nors-a9438476.html.

Nicol, Mark. 2020. China flexes its military muscle: Beijing exploits Covid crisis to assert control of strategically vital South China Sea-And the US sends three warships in response. Daily Mail, 9th May. https://www.dailymail.co.uk/news/article-8304031/ China-flexes-military-muscle-Beijing-exploits-Covid-crisis-asser t-control-South-China-Sea.html.

Noor, Poppy. 2020. What does shaming people who don't social distance actually achieve? The Guardian, 14th April. https://www. theguardian.com/world/2020/apr/14/social-distance-shamingnecessary-coronavirus.

Ó Mongáin, Colm. 2020. Warnings about a global pandemic were ignored-Then Covid-19 struck. RTE, 22nd March. https:// www.rte.ie/news/coronavirus/2020/0321/1124579-should-wehave-been-caught-off-guard-by-covid-19/.

PA Media. 2020. YouTube deletes conspiracy theorist David Icke's channel. The Guardian, 2nd May. https://www.theguardian.com/ media/2020/may/02/youtube-deletes-coronavirus-conspiracy -theorist-david-ickes-channel.

Parveen, Nazia. 2020. Police investigate UK far-right groups over antiMuslim coronavirus claims. The Guardian, 5th April. https:// www.theguardian.com/world/2020/apr/05/police-investigate-ukfar-right-groups-over-anti-muslim-coronavirus-claims.

Pascal, Blaise. 1995. Pensees. London: Penguin.

Perkins, Tom. 2020. Michigan: Right-wing militia groups to protest stay-at-home orders. The Guardian, 13th May. https://www.thegu ardian.com/us-news/2020/may/13/michigan-rightwing-militiagroups-stay-at-home-protest.

Pilkington, Ed. 2020. How science finally caught up with Trump's playbook-With millions of lives at stake. The Guardian, 4th April. https://www.theguardian.com/us-news/2020/apr/04/trump -coronavirus-science-analysis.

Pilkington, Ed. and Tom McCarthy. 2020. The missing six weeks: How Trump failed the biggest test of his life. The Guardian, 28th March. https://www.theguardian.com/us-news/2020/mar/28/ trump-coronavirus-politics-us-health-disaster.

Randall, Ian. 2020. How coronavirus 'deniers' are using Facebook, WhatsApp and YouTube to spread conspiracy theories and misinformation about the deadly disease. Daily Mail, 27th March. https://www.dailymail.co.uk/sciencetech/article-8160809/Howcoronavirus-deniers-using-Facebook-WhatsApp-YouTube-sprea d-misinformation.html.

Regan, Helen. 2020. Air pollution falls by unprecedented levels in major global cities during coronavirus lockdowns. $C N N, 23 \mathrm{rd}$ April. https://edition.cnn.com/2020/04/22/world/air-pollutionreduction-cities-coronavirus-intl-hnk/index.html.

Reuters. 2020. Trump attacks journalists for asking 'snarky' questions on coronavirus testing in US-video. The Guardian, 31st March. https://www.theguardian.com/us-news/video/2020/mar/30/trump -attacks-journalists-coronavirus-briefing.

Robertson, Chris. 2020. Clap for carers: PM joins applause for health workers as he continues coronavirus recovery. Sky News, 16th April. https://news.sky.com/story/clap-for-carers-pm-joins-appla use-for-healthcare-workers-as-he-continues-coronavirus-recov ery-11974399.

Sabbagh, Dan. 2020. UK national security council has not met since January. The Guardian, 12th May. https://www.theguardian.com/ politics/2020/may/12/uk-national-security-council-has-not-metsince-january.

Sartre, Jean Paul. 2000. Huis Clos and other plays. London: Penguin. 
Serhan, Yasmeen. 2020. The case against waging 'war' on the coronavirus. The Atlantic, 31st March. https://www.theatlantic.com/ international/archive/2020/03/war-metaphor-coronavirus/60904 $9 /$.

Shear, Michael D. 2020. Trump attacks W.H.O. Over criticisms of U.S, approach to coronavirus. The New York Times, 7th April. https ://www.nytimes.com/2020/04/07/us/politics/coronavirus-trump -who.html.

Siddique, Haroon, and Sarah Marsh. 2020. Inquiry announced into disproportionate impact of coronavirus on BAME communities. The Guardian, 16th April. https://www.theguardian.com/world /2020/apr/16/inquiry-disproportionate-impact-coronavirus-bame.

Sloterdijk, Peter. 2009. Terror from the air. Los Angeles, CA: Semiotext(e).

Smith, Alexander. 2020a. Trump questions accuracy of China's coronavirus death toll. NBC News, 16th April. https://www.nbcne ws.com/news/world/trump-questions-accuracy-china-s-coron avirus-death-toll-n1185116.

Smith, David. 2020b. Trump throws tantrum over coronavirus question: 'You're a terrible reporter'. The Guardian, 21st March. https:// www.theguardian.com/us-news/2020/mar/20/trump-coronaviru s-question-attack-reporter-over-fears.

Smith, David. 2020c. Trump calls protesters against stay-at-home orders 'very responsible'. The Guardian, 18th April. https:// www.theguardian.com/us-news/2020/apr/17/trump-liberatetweets-coronavirus-stay-at-home-orders.

Solon, Olivia. 2020. Child sexual abuse images and online exploitation surge during Pandemic. NBC News, 23rd April. https://www. nbcnews.com/tech/tech-news/child-sexual-abuse-images-onlin e-exploitation-surge-during-pandemic-n1190506.

Spocchia, Gino. 2020. Trump spent 27 times longer attacking enemies than expressing sympathy for victims, analysis of press conferences shows. The Independent, 27th April. https://www.indep endent.co.uk/news/world/americas/us-politics/url-trump-coron avirus-press-conference-white-house-victims-enemies-a9486 316.html

Strauss, Mark. 2014. Though it seems crazy now, the neutron bomb was intended to be humane. Gizmodo, 19th September. https://io9. gizmodo.com/though-it-seems-crazy-now-the-neutron-bombwas-intende-1636604514.

Sun Tzu. 2020. The art of war. The Internet Classics Archive. http:// classics.mit.edu/Tzu/artwar.html.

Taylor, Philip M. 1998. War and the media. Manchester: Manchester University Press.

Tempterton, James. 2020. How the 5G coronavirus conspiracy theory tore through the Internet. Wired, 6th April. https://www.wired .co.uk/article/5g-coronavirus-conspiracy-theory.

The Economist. 2020. Thanking big brother. The Economist, 18th April. pp. 42-44.

The Guardian. 2020. UK becomes deserted as coronavirus advice bites-In pictures. The Guardian, 20th March. https://www. theguardian.com/world/gallery/2020/mar/20/uk-becomes-deser ted-as-coronavirus-advice-bites-in-pictures.

Tidman, Zoe. 2020. Coronavirus: UK records highest daily death toll of 980. The Independent, 10th April. https://www.independent.co. uk/news/health/coronavirus-uk-death-toll-cases-highest-recor d-latest-a9459916.html.

Timsit, Annabelle. 2020. A Chinese propaganda video mocks America's response to the coronavirus crisis. Quartz, 2nd May. https ://qz.com/1850097/chinese-propaganda-video-mocks-us-respo nse-to-coronavirus-crisis/.

Tucker, Patrick. 2020a. Iran is increasing its military and cyber activity, report says. Defense One, 14th May. https://www.defenseone .com/technology/2020/05/iran-increasing-its-military-and-cyber -activity/165395/?oref=defense_one_breaking_nl.
Tucker, Patrick. 2020b. Iranian, Russian, Chinese media push COVID19 'bioweapon' conspiracies. Defense One, 10th March. https ://www.defenseone.com/technology/2020/03/iran-and-russi an-media-push-bioweapon-conspiracies-amid-covid19-outbr eak/163669/?oref=d1-related-article.

UK Government. 2020a. The health protection (coronavirus, restrictions) (England) regulations 2020. UK Government. http://www. legislation.gov.uk/uksi/2020/350/made.

UK Government. 2020b. Coronavirus (COVID-19): Increased risk of fraud and cybercrime against charities. UK Government, 17th April. https://www.gov.uk/government/news/coronavirus-covid -19-increased-risk-of-fraud-and-cybercrime-against-charities.

Vaneigem, Raoul. 1994. The revolution of everyday life. London: Rebel Press/Left Bank Books.

Virilio, Paul. 1986. Speed and politics. New York: Semiotext(e).

Virilio, Paul. 1994. Bunker archaeology. New York: Princeton Architectural Press.

Virilio, Paul. 1997. Open sky. London: Verso.

Virilio, Paul. 2002. Desert screen. London: Continuum.

Wall Street Journal. 2017. Life inside China's total surveillance state. YouTube, 20th December. https://www.youtube.com/watch $? \mathrm{v}=\mathrm{OQ} 5 \mathrm{LnY} 21 \mathrm{Hgc} \&$ frags $=\mathrm{pl} \% 2 \mathrm{Cwn}$.

Wallace Wells, David. 2020. The white house has erected a blockade stopping states and hospitals from getting coronavirus PPE. Intelligencer, 19th April. https://nymag.com/intelligencer/2020/04/ hospitals-face-a-white-house-blockade-for-coronavirus-ppe.html.

Warrell, Helen. 2020. Defence industry in retreat as coronavirus attacks. The Financial Times, 5th May. https://www.ft.com/conte nt/92959cf4-8ead-11ea-a8ec-961a33ba80aa.

Waterson, Jim, and Alex Hern. 2020. At least 20 UK phone masts vandalised over false $5 \mathrm{G}$ coronavirus claims. The Guardian, 6th April. https://www.theguardian.com/technology/2020/apr/06/ at-least-20-uk-phone-masts-vandalised-over-false-5g-coronaviru s-claims.

Wells, Herbert George. 2019. Book II, Chapter 8: Dead London. The war of the worlds, project Gutenberg. First released July 1992, updated 20th September. http://www.gutenberg.org/files /36/36-h/36-h.htm\#chap27.

WHO. 2019. Ten threats to global health in 2019. World Health Organisation, January, https://www.who.int/news-room/feature-stories/ ten-threats-to-global-health-in-2019.

Williams, Kevin. 1998. Get me a murder a day!. London: Arnold.

Wilson, Jason. 2020. Disinformation and blame: how America's far right is capitalizing on coronavirus. The Guardian, 19th March. https://www.theguardian.com/world/2020/mar/19/america-farright-coronavirus-outbreak-trump-alex-jones.

Woodward, Alex. 2020. Coronavirus: Surgeon General Jerome Adams says Covid-19 is 'Pearl Harbour moment' for this generation as deaths predicted to spike soon. The Independent, 5th April. https://www.independent.co.uk/news/world/americas/coronaviru s-peal-harbour-donald-trump-death-toll-surgeon-general-a9448 411.html.

Young, Sarah. 2020. Coronavirus: 90-year-old Margaret Payne raises $£ 75,000$ for NHS by climbing the equivalent of Mount Suliven on her stairs. The Independent, 17th April. https://www.independen t.co.uk/life-style/coronavirus-margaret-payne-climb-stairs-mount -suliven-nhs-fundraiser-donate-a9470271.html.

Zuboff, Shoshana. 2019. The age of surveillance capitalism. London: Profile Books.

William Merrin is Associate Professor of Media Studies at Swansea University, with specialisms in digital war, digital media and media theory. He is the author of Digital War (Routledge, 2018) and co-editor of The Journal of Digital War. 